\title{
COINCIDENCES, CORRELATIONS, THOUGHTS, PROCESSES: A JOURNEY FROM SPACE TO SILENCE AND BACK
}

\author{
Elisabeth Wildling
}

\section{INTRODUCTION}

In this review I present some insights on my artistic and philosophical studies, showing their impact on the works and processes with which I was engaged during my travels to and within New Zealand and India in 2017 and 2018.'

\section{Space-Silence-Bridging-Subject}

Space and silence are subjects that unite my areas of research and which in hindsight gave me a thread that links my findings. Silence became seminal for me in approaching India and New Zealand, and for fleshing out my artistic processes. This project review draws on my thoughts, processes, and research questions formulated in India which again influenced me on my research stay back in New Zealand at the Dunedin School of Arts.

\section{Artistic Practices}

On the one hand, my research outcomes include expanded practices derived from my immediate artistic investigations such as life drawing and photography. On the other hand, my artistic research interests moved towards an expanded knowledge and understanding of intercultural and transcultural approaches to art and philosophy.

\section{Imagination and space}

What does space mean for an artistic practice? How can one think and go beyond the three-dimensional perspective of space in order to spatialise innertemporal states, as well as to address the questions of time, thought, emptiness and states in between.

\section{SPACE AND IMAGINATION}

In The Poetics of Space, ${ }^{2}$ the French philosopher Gaston Bachelard presents an approach to understanding the impact of space on aesthetic practices through imagination. Bachelard uses the concept of "poetic imagination" to move towards a new, non-Euclidian understanding of space. According to Bachelard,

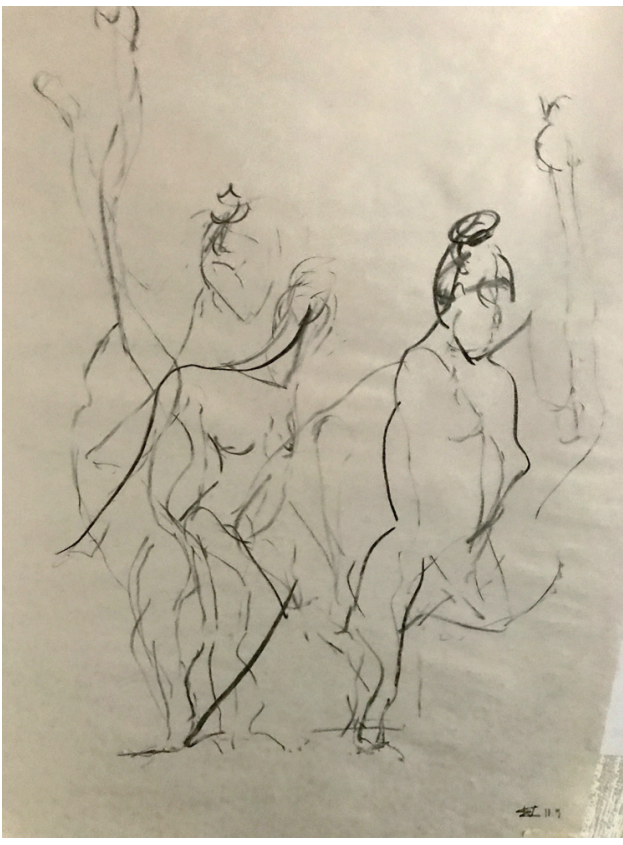

Figure I. Elisabeth Wildling, Untitled, 2017. Life drawing made at the Dunedin School of Art. 

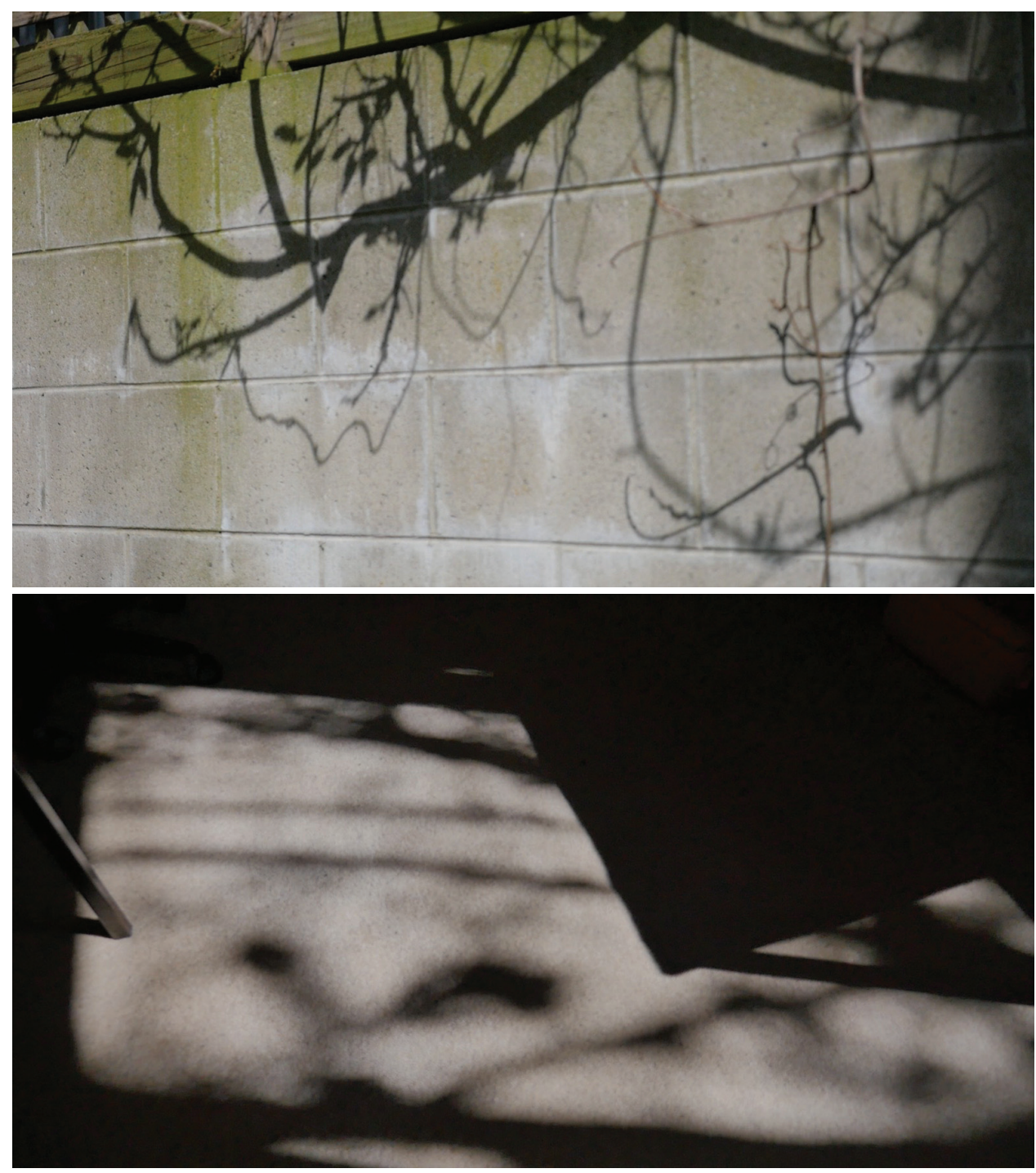

Figure 2. Elisabeth Wildling, pre-photographic images (20|8),

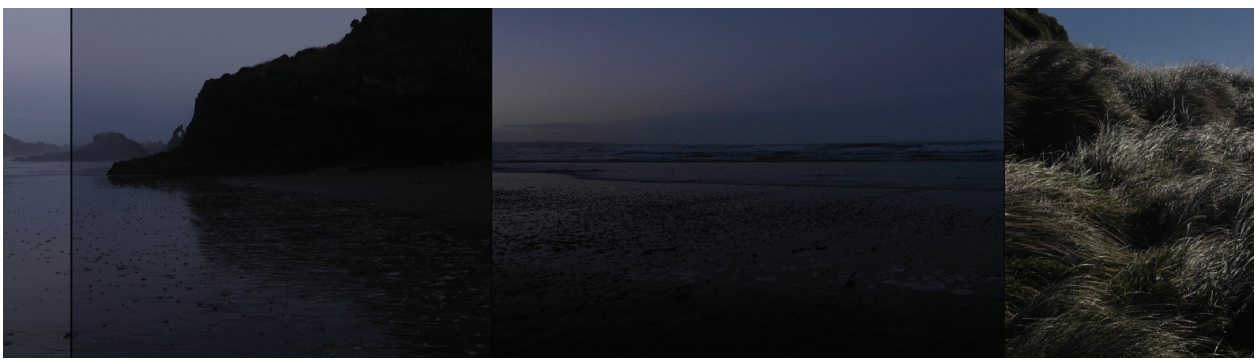

Figure 3. Elisabeth Wildling, Assembled, 20 I8. Being immersed in the land. Crossing the lines of an imaginary landscape on non-selected areas of this montage. 

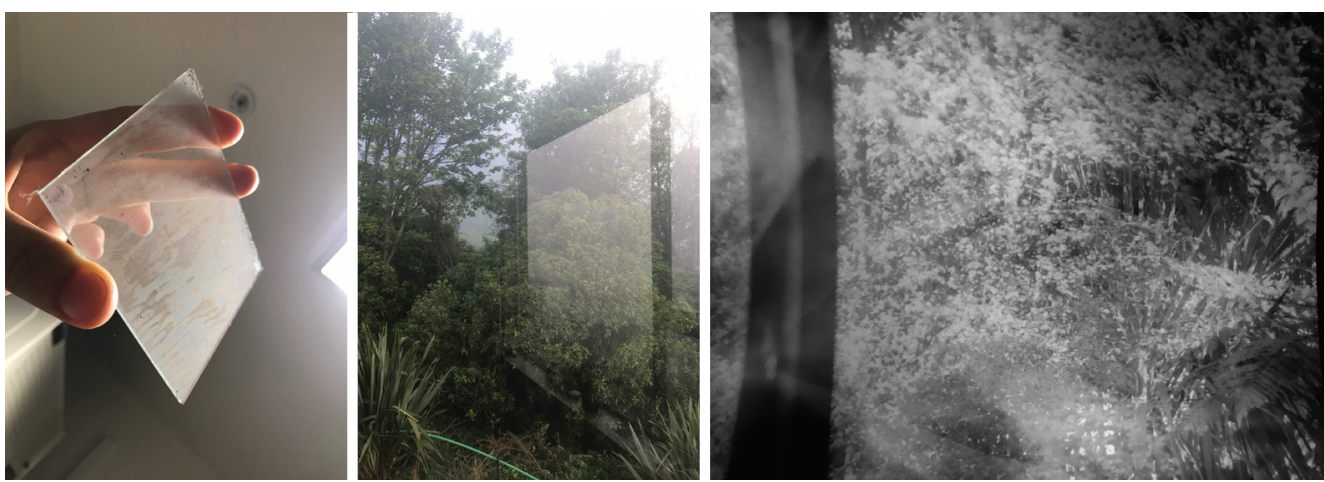

Figure 4. Elisabeth Wildling, Untitled, 20I8, analogue photographic techniques, physautotype, coating glass.

Field studies, Department of Photography and Electronic Arts, DSA.

space is to be sensed via the power of imagination - he understands space as something to be perceived in all its phenomenological and perceptual complexity. Therefore, due to imagination, spaces and places become zones of perceivable vastness.

Following Bachelard, the "poetic image" is not to be seen as an image that derives from thinking, reconstructing or recollecting. On the contrary, it is a new image that has never before existed or been constructed.

Through what he calls reverberation - the opposite of causality - Bachelard believes that the real nature of a poetic image can be found. "In this reverberation, the poetic image will have a sonority of being. The poet speaks on the threshold of being. [...] In the resonance we hear the poem, in reverberation we speak it, it is our own." ${ }^{3}$

Ideas about imaginary space and the spatial potential of a point or a line can be found in the work of Russian artist, designer and theorist El Lissitzky, who talks about the correlation between space and object. In addition to the act of perceiving a static object, Lissitzky suggests the concept of movement. So, for example, a material point can form a line when being moved. The movement of a material line produces an impression of an area and a body. When an inert material is moved, it forms an entirely new object as long as the movement lasts and is therefore imaginary. El Lissitzky also "saw vast potential for new expressions of space through the unlimited discovery of photographic means." The term "imaginary space" is also related to a phrase used by El Lissitzky and developed in his famous essay "A. and Pangeometry," first published in Germany in 1925."

Josef Albers (Germany/America, Bauhaus) expanded the notion of the viewing space creating structural constellations and geometrical depictions of two-dimensional space, resulting in polymorphic possibilities. Here, the direction of possible movements was changeable; a single contour belonged to more than one layer, and the axonometric image was reversible.

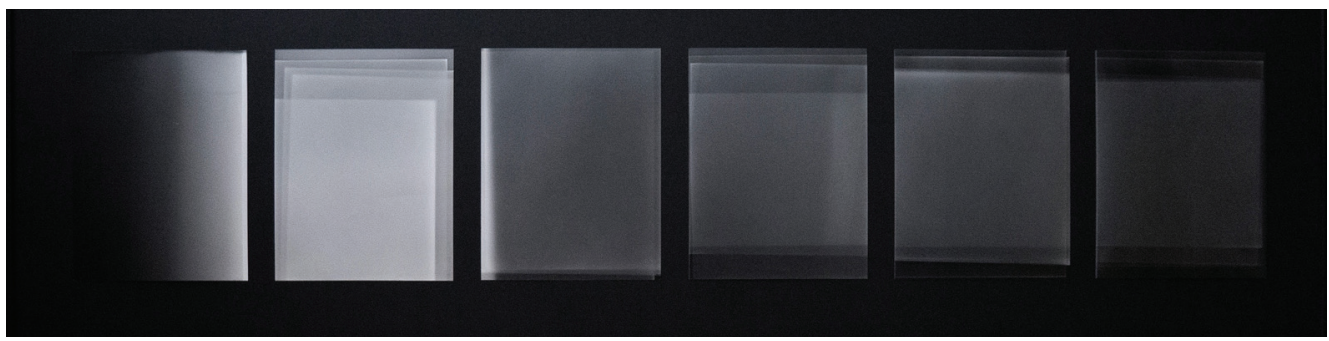

Figure 5. Elisabeth Wildling, Untitled, 20 I 8, photograms. Light, Time, Space. 
Space and imagination are also central issues for life drawing. The artist sees and creates marks by depicting light and shadows on paper, using charcoal or pencil. During this process, the fingers build a structure with the pencil providing the model with perspective and distance, focusing on it and observing it - a finger-pencil assemblage, as Deleuze would put it.

If phenomena are descriptions of things as one experiences them, this description includes experiences of both what is actual and what is virtual. In measuring the dimensions of a situation, imagination may envision what is not present. The images and field studies of my work as reproduced here can be seen as an artistic response inspired by the concept of an imaginative space - discovering the virtual dimension amid actual perceptions and drawings.

\section{THE UNITY OF THEORY AND PRACTICE}

I participated with ten other artistic researchers in a residency in South India in early 20 I 8 called "In a Silent Way."6 Besides preparing for a field performance in Delhi, we practiced yoga, which included reading, discussing and reciting the Yoga Sutras - short phrases containing the essence of the path of yoga, written down by Patanjali around 200 $\mathrm{BC}$. In India, because there is a strong oral tradition, primary theoretical texts are often short and concise in order to be learned and recalled by heart. In practice, reciting these short texts induces a calming and meditative state.

In non-dualist Kashmir Shaivism (the basis of contemporary Tantrism) there is no separation between object and subject. Our inner essence is not believed to be different from the essence of the world. Hinduism and Buddhism share strong similarities when it comes to realising that the individual is not a separate entity. Kashmir Shaivism

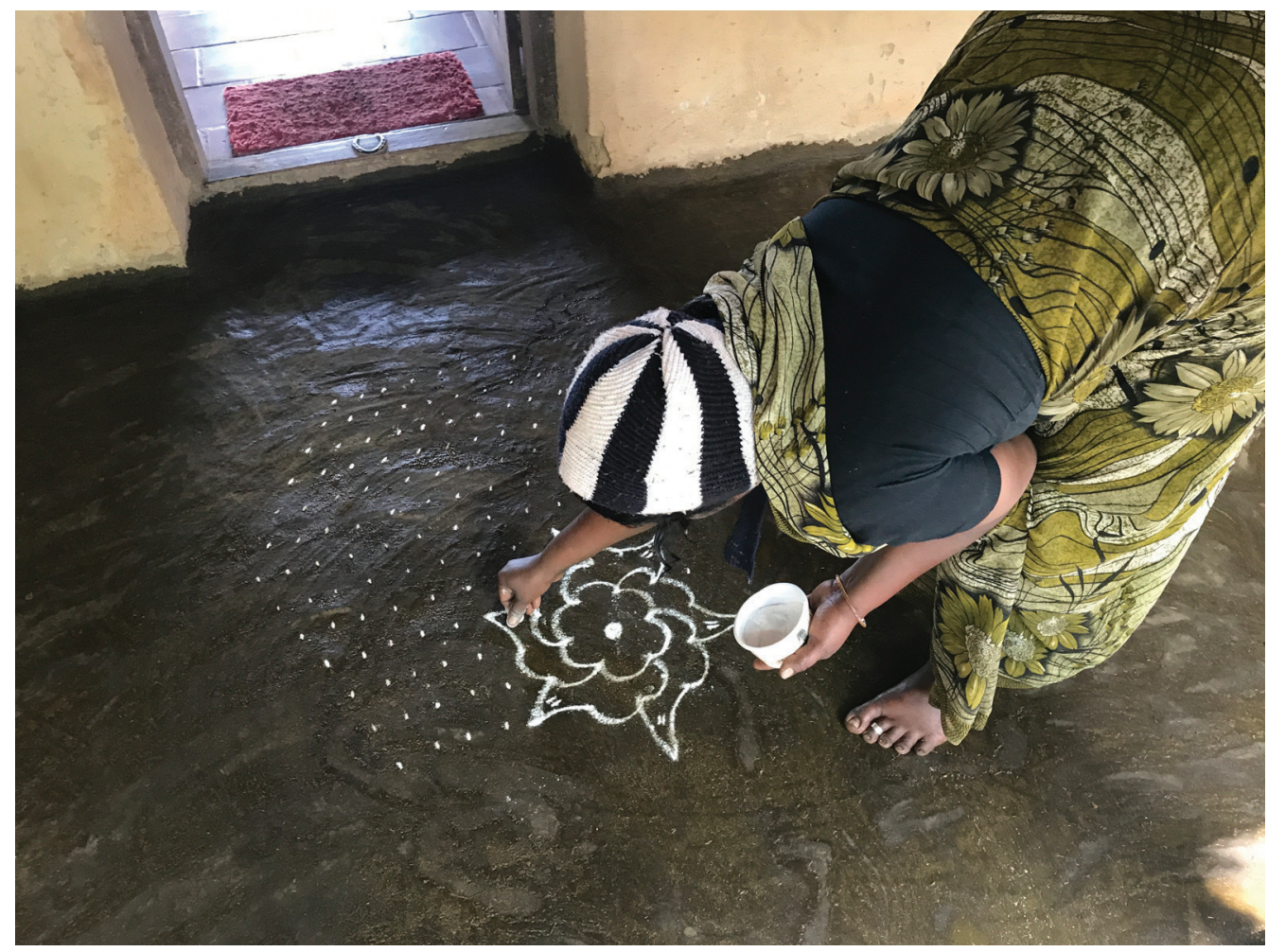

Figure 6. Indian housekeeper drawing a kolam, Kodaikanal, India (20।8). Her posture reflects deep concentration and presence within body and mind, representing the formation of silence. Photograph: Elisabeth Wildling. 
provides a 'theory' of the relationship between tension and vibration where things oscillate and are in relationship to other things. It emphasises that it is the relationships between objects that make us understand the world. As a result, it questions whether things are isolated in in reality. This 'theory' instead suggests that things are vibrating states which we cannot isolate completely from other things. ${ }^{7}$

In the Indian context, philosophy does not just mean theory but also practice, bodily labor, including practices like thinking, reading, writing, questioning, arguing. Thinking is not separated from aesthetic or bodily experiences. There is no separation between body and mind, nor between theory and practice.

At the residency house in Tamil Nadu, the housekeeper, was drawing her weekly kolams ${ }^{8}$ on the floor, which was made of compacted cow dung. Her body was in a stable and grounded position while she constructed the patterns, and she was in a state of deep concentration. Her whole body was in a state of "reflective awareness." Making a big jump to Western philosophy, I seek to connect these reflections with Gilles Deleuze and Félix Guattari's concept of the "machine désirante" in Anti-Oedipus. ${ }^{10}$ There are good reasons for understanding yoga in the sense of a union of a multitude, a synthetic unity achieved through stable conjunction. Yoga literally means "a process of yoking, union.".'

The relationship between the posture and the immersive concentration of the Indian housekeeper and observational drawing now becomes evident. There is a parallel between her unified state and between silent presence and bodily awareness in life drawing.

\section{SILENCE AND SELF-EMPTYING}

What is silence? What can silence add to one's own artistic practice? Imagining silence as a place full of potentialities for understanding and enabling sensitive contact for an aesthetic, material reality are the second emphases of this project report. I address the question of being receptive to the meaning of sensitive emptiness as the highest form of receptivity.

The concept of nirodha, introduced in the second Yoga Sutra and a central motif in Indian culture and philosophy, helps us understand the qualities of silence and emptiness. Yogas-citta-vrtti-nirodhah - "Yoga is [meant] to still the patterning of consciousness."'12

"One has to learn to imitate the silence on the bottom of the sea, with one's own body, to experience nirodha. One has to realize it bodily, becoming silent, as if one were dead before one is actually dead."'13 In the context of yogic theory, philosophical practice aims exactly at this sensual transformation of our bodily existence. "Only when we realize the innermost core of the world within our own bodies will silence happen."'14

The cessation of the mind can also happen when we breathe out and when an empty space arises in the stomach: "At the dead point of the breath, which lies between the breathing in and out, we can experience a form of nothing. Nirodha, a silent joy, empties us of ourselves." ${ }^{\text {.15 }}$

\section{SILENCE AND TOUCH}

As I mentioned above, when reflecting on the relationship between subject and object, according to the intercultural and transcultural philosophy of Indian aesthetics, all bodies are considered to be vibration centres, resonating with all other bodies, beings or things in the universe. Bodies are always already in touch with their surroundings.

When two objects encounter each other, that is a form of touch. Can one be touched by doing nothing more than watching leaves on a tree, objects which are slowly and spontaneously being moved? 
My work Touching Silence, Still (Figure 7) addresses the immanent relationship between object and space, the lightlikeness of objects and their being affected by the forces of wind and sunlight in an immediate but often subtle, silent way.

\author{
What kind of space is this, which has yet been provided? \\ What if we raise our awareness, if we sensitise ourselves? \\ A mutual connection of touching. \\ Thinking in terms of interrelationships. \\ The stillness of a tree, \\ the gentle moving of the leaves, \\ silently touching something within myself.
}

Watching the leaves and experiencing this process of encountering - this might become a sensual, embodied experience. What moves me to silence and happiness is an atmosphere created by moving elements in nature, things which are not moved by human intention. Leaves, branches, trees, nature, all being moved by the wind and touched by the sun. Things being moved unpredictably intensifies our sense of the unforeseen and the ability not to know what will happen and the way in which something will be moved. This underlines the idea that space is filled with vibration and that everything is connected in some way.

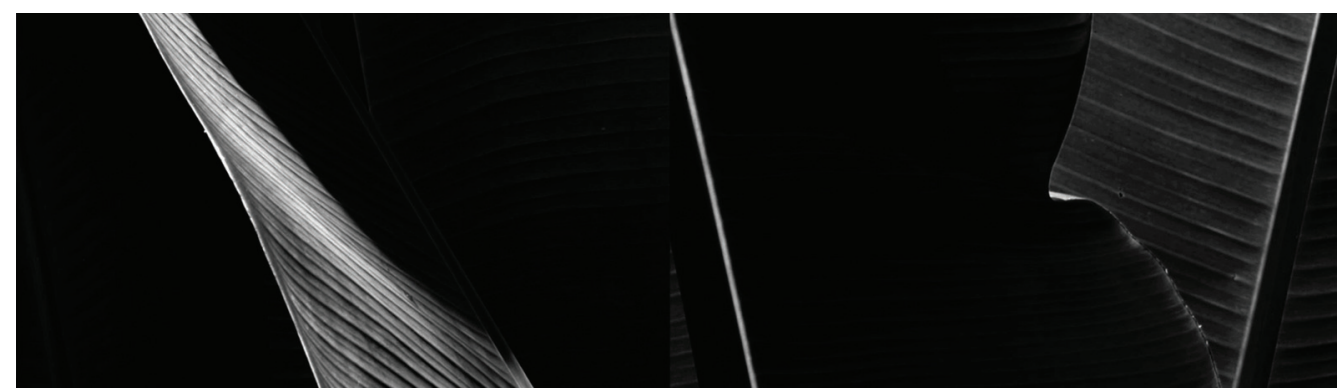

Figure 7. Elisabeth Wildling, Touching Silence, Still, 2018, 2-channel video projection. Shown at the Philosophy Unbound - DETEXT festival, New Delhi, India, 2018.

Elisabeth Wildling is a multi-disciplinary artist from Vienna, -Austria, where she works both as an artistic and scientific associate at the University of Applied Arts and as a lecturer at a college of higher technical institution in Vienna. She is engaged in research in philosophy and art and is currently undertaking a $\mathrm{PhD}$ at the University of Applied Arts Vienna. 
I As a staff member at the University of Applied Arts Vienna and at the same time undertaking a PhD, I took up the post of visiting research scholar at the Dunedin School of Art, Otago Polytechnic. Following this exchange, I spent three months in India as part of a collaborative residency program called "On the Significance of Silence in the Arts, Philosophy and Contemporary Forms of Life," which resulted in some work that I completed on my return to Dunedin in 20 I 8.

2 Gaston Bachelard, The Poetics of Space (Boston, MA: Beacon Press, 1994 [1964]), xix.

3 Ibid, $x$ vi.

4 Poetics of Space: A Critical Photographic Anthology, ed. Steve Yates (Albuquerque, NM: University of New Mexico Press, 1995), 64.

5 El Lissitzky, "A. and Pangeometry," in Europa-Almanach, eds Carl Einstein and Paul Westheim (Potsdam: Gustav Kiepenheuer Verlag, 1925), 103-13.

6 "In a Silent Way," Artistic Research and Arts-based-Philosophy Residency,Tamil Nadu, India, 2018.

7 The Stanzas on Vibration, ed. Mark SG Dyczkowski (Albany, NY: State University of New York Press, 1992).

8 Kolams are a ritual form of drawing constructed patterns with dried rice flour or powdered white stone. Women in Tamil Nadu draw these designs each morning on the floor, or in front of the house, in order to welcome the goddess Lakshmi into the house. http://indian-heritage.org/alangaram/kolams/kolams.htm (accessed 5 August 2019).

9 The Stanzas on Vibration, 43.

10 https://www.britannica.com/topic/Yoga-philosophy__accessed 5 August 2019).

II Gilles Deleuze and Felix Guattari, Anti-Oedipus: Capitalism and Schizophrenia (Minneapolis, MN: University of Minnesota Press, 1983).

12 Chip Hartranft, The Yoga-Sutra of Patanjali (Boston, MA: Shambhala Publications, 2003).

13 See Jacques Derrida, As if I were Dead/ Als ob ich tot wäre (Vienna: Passagen, 2000).

I4 Arno Böhler, "Kunst und Philosophie im Zwischen der Kulturen," Polylog: Zeitschrift für interkulturelles Philosophieren, 35 (20I6), 16 (email conversation).

15 Arno Böhler, "Dem Werden der Natur entgegenkommen: Ein Interview von Stefanie Haller mit Arno Böhler über die Yoga-Sutren von Patañjali," u:scholar, https://uscholar.univie.ac.at/view/o:683303 (accessed 5 August 2019). Böhler's article "Meditation in the Context of Indian Philosphy: Patañjali's Yoga-Sutras" formed the basis of this interview. 